\title{
Analysis of the Activities of Land Administration Machineries in Abuja and Minna, Nigeria
}

\author{
${ }^{1}$ Ayoola A. Babatunde, ${ }^{2}$ Kemiki O.A.(PhD), ${ }^{3}$ S.Abdulkareem, ${ }^{4}$ F. Fabunmi \\ Department of Estate Management \& Valuation, Federal University of Technology, Minna, Niger State,Nigeria.
}

\begin{abstract}
This study attempts to have a comparative analysis of the activities of land administration machineries in FCC, Abuja and Minna using some selected districts and neighbourhoodsas case study areas. Questionnaires were administered to Individual land owners, property developers or plot allottees who own land from ages Eighteen (18) and above as well as interview to somestaff of departments of land administration machineries in FCC, Abuja and Minna. Statistical Package for Social Scientists (SPSS), Geometric Mean Model and Linkert Scale were statistical tools employed. Findings revealed that the average growth in land allocations made available to people by government within the study period of 2000 - 2009 in FCC and Minna were $191.25 \%$ and $29.22 \%$ respectively. In FCC, Delay of process and extortion of money by government officials are sufficient reasons why individual land owners will not be willing to process title documents to land. While in Minna, the reasons are Exorbitant Processing Cost, Delay of Process and extortion of money by government officials. The paper suggests among others that land administration officials should abstain from illegal acts during land transactions, government should ensure that adequate income packages are paid to land administration officials and ensures enlightening and educating customary land owners on the need for compulsory acquisition.
\end{abstract}

Keywords: land administration, land allocation, title document

\section{Introduction}

Land has been recognized as a primary source of wealth, social status, and power. It is the basis for shelter, food, and economic activities; it is the most significant provider of employment opportunities in rural areas and is an increasingly scarce resource in urban areas. Access to land then is an important aspect of household, community, and national decision-making powers. Access to land is governed through land tenure systems. Land tenure is the relationship, whether legally or customarily defined, among people, as individuals or groups, with respect to land (Food and Agriculture Organization of United Nations, 2010)

In Nigeria, the Land Use Act which was promulgated in March, 1978 is presently Nigeria's highest land administration instrument.The Decree abolished the Freehold, that is, the Fee Simple Estate which was previously existing in the Southern Part of the country. And it reduced all titles to land to rights of occupancy not exceeding Ninety-Nine (99) years. Therefore, all Freeholders became Lessees of their various state governments. The Decree also limited the amount of land that could be legally held by individual to not more than half a hectare in the urban areas of any state. (Ayedun and Oluwatobi, 2011).

Unfortunately, the national land policy, the Land Use Act which was promulgated in 1978 with the intention of making land readily available and accessible to all eligible Nigerians, has ended up constituting itself into clog in the wheel of housing provision and other development projects in the country.(Babade, 2003; Omirin, 2003; Ayedun and Oluwatobi, 2011). It is within this analytical context that this research work tends to carry out an analysis of the activities of land administration machineries in Abuja and Minnawith a view to understanding the various problems associated with land accessibility in our urban centres.

\subsection{Problem Statement}

Access to land has become easier and cheaper for public use with the promulgation of the Land Use Act of 1978 but access to land for private development appears to have become even more difficult than ever before.(Omirin, 2003).The Land Use Act has given rise to certain agencies of government on land issues. The success stories from these agencies of course will depict the extent of realisation of the objectives of the Land Use Act. The Extremists view on the Land Use Act is that the Act is not only bad but incurably bad and that there is only one remedy to it which is abrogation to give room for a new beginning. The Moderates view on the other hand is that whether the criticisms against the Act are legal, administrative or a combination of both, it is too late to think of abrogating it, rather, they prefer a comprehensive review (Iseh, 2003). Also, land availability and ineffective land administration have been identified as the major factors militating against housing development in Nigeria despite the existence of the Land Use Act over the past thirty (30) years (Stanley and Orobowale, 2011 in Iseh, 2004). 
The question that readily comes to mind is,to what extent is land made accessible for urban development by the land administration machineries at the study areas? What is the level and challenges of processing of title documents to land by private developers at the study areas? What are the challenges militating against government in making land available for private development to peopledespite the enormous powers of the Land Use Act? These are some of the pertinent issues to which this research work tends to provide answers to by analysis the activities of land administration machineries in Northern Nigeria, with specific reference to Abuja and Minna.

\subsection{The Study Areas}

Abuja, Nigeria's new capital city is located in the middle of the country. The Federal Capital Territory has a land area of 8,000 square kilometres, which is two and halftimes the size of Lagos, the former capital of Nigeria. As at now, the Federal Capital City (FCC) which is the study area is planned to cover an area of about 250sq.kms (25,000 Hectares) while the rest of the territory of the city region covers about 7,750 sq.kms. It falls within latitude $7^{\circ} 25^{\prime} \mathrm{N}$ and $9^{\circ} 20^{\circ}$ North of the Equator and longitude $5^{\circ} 45^{\prime}$ and $7^{\circ} 39^{\prime}$. Abuja and the FCT have experienced huge population growth. It has been reported that some areas around Abuja have been growing at $20 \%$ to $30 \%$ per year. At the 2006 Census, the city of Abuja had a population of 1,414,201.The projected population figure for 2012 is 1,688,630.As at today, 107 districts have been opened in Abuja. Only 13 districts have been developed so far.

Minna lies in latitude $9^{\circ} 37^{\prime}$ north, longitude $6^{\circ} 37^{\prime}$. It is located on a plain and gentle slope valley. The city has a total land area of about 6,784 square kilometres. The present population is heterogeneous with considerable numbers of people from different parts of Nigeria. The highest proportion of the population is composed of Gwari, Hausa, Nupe and Non-natives residing in Minna. According to the 1991 census conducted by the National Population Commission (NPC) the population of Minna was about 157,159. By the 2006 Population and Housing Census Figures, Minna has a population of 348,788. The projected population figure by 2012 is 416,471. Meaning that Minna has grown by 54\% in Fifteen (15) years. Minna, as at today is made up of Chanchaga and Bosso Local Government Areas. Chanchaga Local Government is made up of Eleven (11) Wardswhile Bosso Local Government consists of Ten (10) Wards.

\subsection{Definitional Concepts \\ 1.3.1 Land Tenure}

Land tenure refers to the rules, authorities, institutions, rights and norms that govern access to and control over land and related resources (International Fund for Agricultural Development, 2010).United State Agency for International Development (2010), collaborates the view of International Fund for Agricultural Development (2010) that land tenure is the institutional (political, economic, social, and legal) structure that determineshow individuals and groups secure access to land and associated manage land resources such as trees, minerals, pasture and water but that such rules and control should stipulate how long and under what conditions will land and related resources be held and use by people that have access to it. The Agency also added that land tenure may have both spatial and temporal dimensions and are typically defined through statutory or customary law. Ogedengbe (2004), sees land tenure as a basic instrument of overall development policy, performing both an indirect facilitating role and a direct and active one. He emphasized that land tenure is a major determinant of the local tax base and significantly affects the quality and return of investment undertaken in land and structures.In Nigeria, access to land is governed by the Land Use Decree NO.6 of 1978 which brought together our proprietary land rights system to form a single entity.

\subsubsection{Land Management}

Land management involves the timelines with which processed land is made available in adequate amounts, at right location and at affordable prices to the people of a country in a way to ensure its optimum use in terms of efficiency, equity and the meeting of their basic human needs.(Mabogunje, 2003). According to Omirin (2003), Public land Management is to guarantee equitable distribution of land rights on the basis of non - commercial criteria; empower government to ensure a more judicious, orderly and healthy development of urban areas; guarantee cheaper and access to land for both public a private land development as well as curb speculation which was believed to be the main cause of escalating land prices in the periphery. Gamu (2003), opines that Land management can be viewed in terms of land accessibility, land tenure systems and processes, land distribution, land use physical planning and control as well as land administration and taxation.United Nations Economic Commission for Europe (2005)describes land management as the processes whereby the physical resources of land are put to good effect regardless of the fact that the land may be owned by the State, a legal entity or a private individual.In Abuja, the Land Administration Machineries at the Federal Capital Cities (FCC) constitute the Land Administration Department, Urban and Regional Department, Survey and Mapping and Abuja Geographical Information Systems (AGIS), while in Minna, the Ministry for lands and Survey is 
saddle with the responsibility of making formal land available to the residents. These machineries in Abuja and Minna engage inroutine operational decisions on land and ensure that there is economic balancing of land uses at the urban centres.

\subsection{The Land Use Act/Land Accessibility}

Omirin (2003) says that access to land in Nigeria is affected by the operation of the Land Use Act of 1978 creating more of a bottleneck. She stresses that the provisions give the government cheap control of much land, but the allocation criteria are so exclusionary as to provide access to only a very small proportion of upper income earners, particularly the educated elite, the politically influential and military personnel.Ayedun and Oluwatobi (2011) note that the Land Use Act was promulgated with the intention of streamlining the land tenure systems in the country by vesting the ownership and title to all lands in the country on the Governors of the respective states of the Federation for the purpose of easy management and accessibility by those interested in the acquisition of lands in the country. He however stressed that the contentious issues of Governor's consent for any subsequent transaction in land and the intractable government bureaucracy and bottlenecks have made the procurement of land problematic, unnecessarily expensive and out rightly out of the reach of most of Nigerians citizens most especially in the urban centres of the country.

Babade (2003) citing De Soto (1990) mentioned that the land acquisition process is long, cumbersome and frustrating in many developing countries of the world. State allocation of land for instance involves six stages of processes lasting an average of 43 months in Peru. It involves the president of the Republic as well as 207 bureaucratic steps involving 48 different government offices and at the end of it all, the property rights remain unclear. Asiamia (1990) in Babade (2003) stressed that access to land in Ghana although is made on first-come-first-served is also complicated as it can take several months before allocation is done.These works spelt out how frustrating the land allocation process could be to applicants. However, it did not reveal the problems militating against the land administration agencies neither did it show the extent to which people have benefitted from the process even though it is frustrating.

Stanley and Orobowale (2011) assessed the factors associated with land accessibility for housing development in the Federal Capital City (FCC), Abuja. Individual land owners were randomly selected at the FCC. Out of the respondents administered questionnaires on, $63.64 \%$ have in one time or the other applied for land while $36.36 \%$ had never applied at the department of land administration. They noted that $38.09 \%$ of the respondents that applied for land got land allocation while the remaining $61.9 \%$ were denied allocation because of non-compliance with the requirement.On the other hand, $33.33 \%$ of the respondents that have refused to apply for land with government attributed it to lack of fund, $25 \%$ indicated that it was due to ignorance while $41.67 \%$ were discouraged to apply as a result of the level of apathy that could be meted on them. The Authors therefore suggested amongst others that land application for housing development should be encouraged, applicants should be given equal chances and financial institutions should relax the stiff conditions laid down to obtain fund without high interest and collateral.This work has only showed the activities of land administration from citizens perception but has not looked at the activities of land administration machineries from staff perspective. This research work on the other hand will look at the efforts of the land administration machineries over a time lag.

\section{Research Methodology and Data Collection}

In order to establish and assess the modes of access to land in Abuja and Minna, information is required from people with access to land which is mainly primary in nature. The Federal Capital City (FCC) in Abuja and Minna were subdivided into Districts and Neighbourhoods using Cluster Sampling. Five (5) districts in the FCC which are in phase 1 and Eight (8) Neighbourhoods in Minna are selected using partly captive and random samplingtechniques respectively. Questionnaires were administered to residents from Eighteen (18) years and above in FCC and Minna which is the age category of people who are eligible to own land in Nigeria.

The National Population Commission 2006 Population Census was relied upon for Abuja (Nuhu, 2011), While the 2003 population census figures were adopted from Sanusi, 2006 and adopted for the neighbourhoods in Minna. Population projection formula, $\operatorname{Pr}=\operatorname{Po}(1+\mathrm{r} / 100)^{\mathrm{n}}$, was therefore used to project the population figures for the required period. The population of the persons from 18 years and above, for Minna and Abuja are $47.5 \%$ and 53.4\% respectively gotten from NBS/NPC Social-Economic Survey on Nigeria, 2006. Sample size is determined by the formula, $\mathrm{S}=\frac{\mathrm{N}}{1+\mathrm{N}(\mathrm{e})^{2}}$ (Israel, 2009)

So, 1865 Questionnaires and 3096 questionnaires were administered on the respondents across the five (5) districts and eight (8) Neighbourhoods in FCC and Minna respectively using systematic random sampling technique.

Data on the extent to which land is made available to people at the study areas came from the records of Abuja Geographical Information Systems (AGIS) and Land Section of the Ministry of Lands and Survey, 
Minna.Interview with some staff of the land administration machineries at the study areas revealed the factors militatingagainst the performance of the agencies.

Variables such as exorbitant processing cost, delay of process, extortion from government officials and lack of how to go about processing title were derived from respondents' perceptions as factors militating against the desire of respondents to processing Certificates of Occupancy ( $\mathrm{C}$ of $\mathrm{O}$ ).Likert ranking of the variables was done to arrive at their mean values.

The results of the research is presented in the subsequent section.

\subsection{Modes of Access to Land in the Study Areas}

\section{Findings/Discussion}

The roads of access to land which are explored by land owners at the study areas are Private purchase, local government allocation, state government allocation, inheritance and gift. Table 3.1 shows how lands were acquired across the sampled property developers and individual land owners or plot allottees

\begin{tabular}{|c|c|c|c|c|c|c|}
\hline & FCC & & & Minna & & \\
\hline Modes of access to land & Frequency & Percent & $\begin{array}{l}\text { valid } \\
\text { percent }\end{array}$ & Frequency & Percent & $\begin{array}{l}\text { valid } \\
\text { percent }\end{array}$ \\
\hline private purchase & 544 & 29.2 & 67.8 & 1252 & 40.1 & 66.3 \\
\hline Local government allocation & 132 & 7.1 & 16.5 & 135 & 4.3 & 7.2 \\
\hline Federal or state allocation & 94 & 5 & 11.7 & 262 & 8.4 & 13.9 \\
\hline Inheritance & 22 & 1.2 & 1.3 & 205 & 6.6 & 10.9 \\
\hline Others e.g gifts & 10 & 0.5 & 2.7 & 33 & 1.1 & 1.8 \\
\hline Total & 802 & 43 & 100 & 1887 & 60.6 & 100 \\
\hline Missing system & 1063 & 57 & & 1209 & 39.4 & \\
\hline Total & 1865 & 100 & & 3096 & 100 & \\
\hline
\end{tabular}

Source: Author's Fieldwork (2011)

In FCC Abuja, 29.2\% of the approximate $43 \%$ respondents that own land said that private purchase is the source of their access to land, $7.1 \%$ for local government allocations, while state allocation as mode of access to land accounted for $5.0 \%$. From the response, it is clear that informal land market is a fundamental source of access to land at the study areas. The formal land market from the perception of the land owners has also supplied $12.1 \%$ of the land owners with land.

In Minna, the responses reveal that private purchase earned a high score of $40.1 \%$ of the approximate $60.6 \%$ respondents means of access to land and on the other hand local and state government allocations earnedscores of $4.3 \%$ and $8.4 \%$ respectively on the extent from the perception of the respondents to which formal land are made available to the sampled property developers and individual land owners or plot allottees.

\subsection{ANALYSIS OF THE ACTIVITIES OF LAND ADMINISTRATION MACHINERIES IN FCC AND} MINNA

\subsubsection{Agencies responsible for Provision/Allocation of Land in FCC}

The Land Administration Machineries at the Federal Capital Cities (FCC) constitute the Land Administration Department, Urban and Regional Department, Survey and Mapping, and Abuja Geographical Information Systems (AGIS). The Land Administration Department is saddle with the responsibilities of making formal land available to Applicants for land.The Land Use Decree No.6 of 1978 and FCT Act Cap F6 LFN 2004 are statutory powers that back the functions of Land Administration at the Federal Capital Territory, Abuja.

\subsubsection{Agencies responsible for Provision/Allocation of Land in Minna}

The Ministry for lands and Survey is saddled with the responsibility of making formal land available to the residents of Minna. Land Section, Town Planning Section, Survey Section, Planning Research and Statistics Section, Legal Section, Administration Section, Geographic Information Systems (GIS) Section, Architecture, Building and Quantity Surveying sections are instrumental to the activities of the Ministry. The Land Use Decree No.6 of 1978 is the statutory power that backed up the functions of land administration in the ministry. The staff strength of the ministry is Three Hundred and Fifty-One (351).

\subsubsection{Extent of Residential Land Allocations to Residents in FCC and Minna between 2000 - 2009}


The land allocations done by the department of Land Administration in the Federal Capital City and Ministry of Lands and Housing in Minna for the years 2000 to 2009 are as shown in Tables 3.2 and 3.3

Table 3.2 : Residential Land Allocations by department of land administration in FCC, Abuja, 2000 - 2009

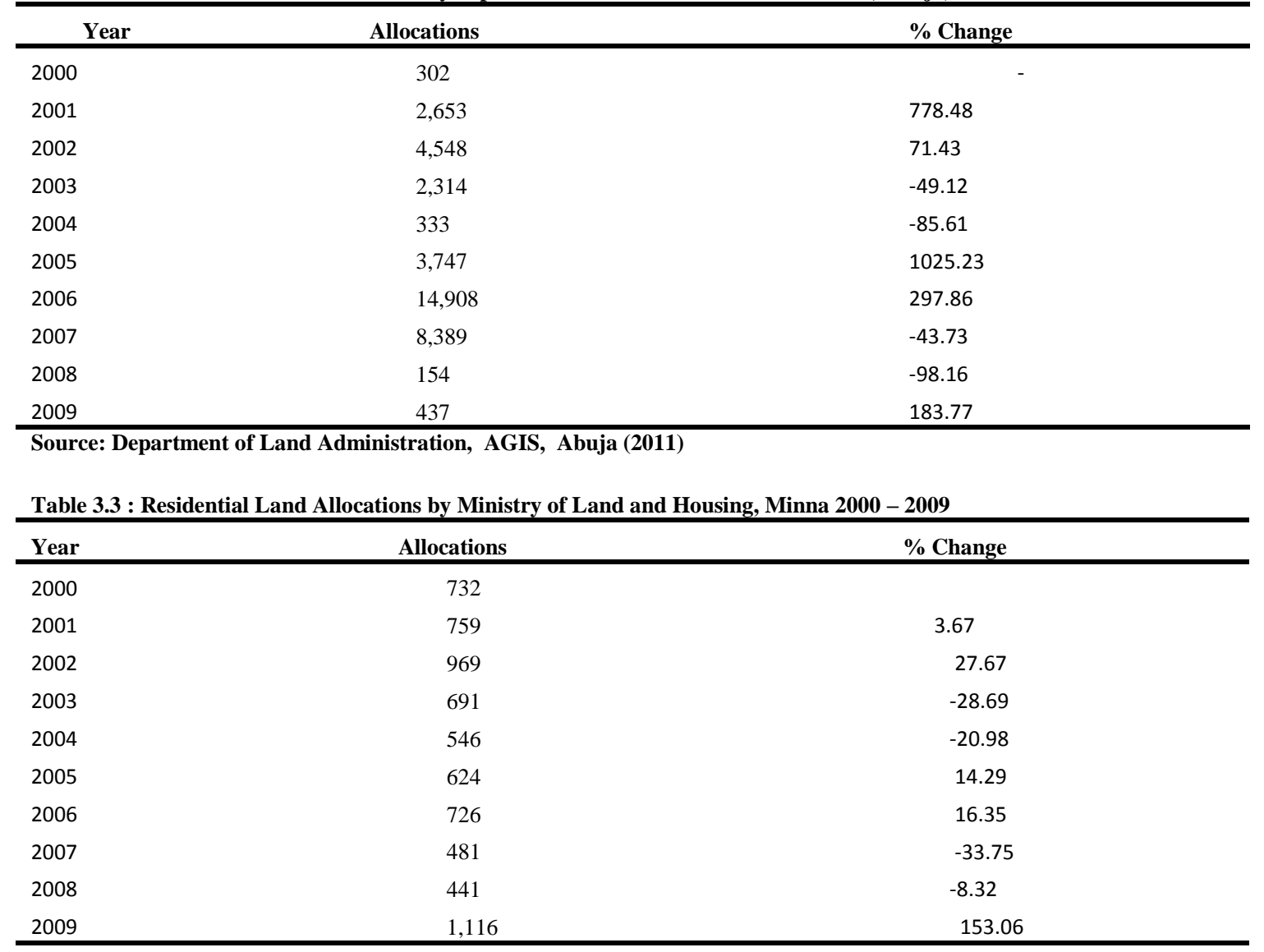

Source: Ministry of Lands and Housing, Minna (2011)

Percentage $(\%)$ change in residential allocations by Department of Land Administration in the Federal Capital City and land allocations by Ministry of Lands and Housing in Minna were determined as presented in Tables 3.2 and 3.3 respectively. It was discovered that within the study period, there were growth and decline in land allocations within the study period. In order to obtain the average growth rate, the geometric mean model was used. The geometric mean was calculated using the following expression:

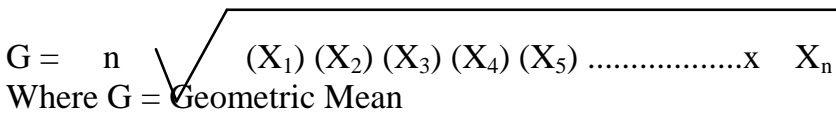

$\mathrm{n}=$ Total number of years within the study period

$\mathrm{X}_{1} \ldots \ldots \ldots \ldots . . . . \mathrm{X}_{\mathrm{n}}=$ Annual growth rates in land allocations within the study period.

The average growth in land allocations in FCC $(2000-2009)$ is calculated as follows:$\mathrm{G}=9 \sqrt{\begin{array}{c}(8.7848)(1.7143)(-1.4912)(-1.8561)(11.2523)(3.9786)(-1.4373)(-1.9816) \\ (2.8377)\end{array}}$

$\mathrm{G}=9 \sqrt{15081.95}-1$

Hence, although land allocations by Department of Land Administration in FCC changed at various rates within the study period, the average rate of change in land allocations for the entire period is $191.25 \%$

Also, the average growth in land allocations in Minna (2000 - 2009) is determined as follows:-

$\mathrm{G}=9 \quad(1.0367)(1.2767)(-1.2869)(-1.2098)(1.1429)(1.1635)(-1.3375)(-1.0832)$

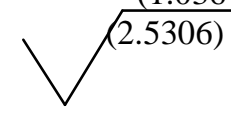

$\mathrm{G}=9 \sqrt{10.0461788-1}$ 
$\mathrm{G}=1.292211-1$

$\mathrm{G}=29.22 \%$

The average growth in land allocations for the entire period in Minna is $29.22 \%$

It therefore means that the extent to which land is made available to individuals or organizations by land administration department in FCC is highly favourable than in Minna.By implication, it means development is more active in Abuja (growth rate of 191\%) than in Minna (growth rate of 22\%). In other words, developers are more interested in accessing land for real estate development in Abuja than in Minna within the study period. Also, the rate of development in Abuja has revealed through the results of data analysis is higher than that of Minna.

\subsubsection{Respondents' Opinion on Problems to Processing of Title Documents}

The level of possession of certificate of occupancy by private developers at the study areas is shown in Table 3.4

\begin{tabular}{|c|c|c|c|c|c|c|}
\hline Variables & FCC & & & Minna & & \\
\hline & Frequency & Percent & Valid Percent & Frequency & Percent & Valid Percent \\
\hline Possess $\mathrm{C}$ of $\mathrm{O}$ & 438 & 23.5 & 60.8 & 748 & 23.0 & 39.6 \\
\hline Do not have $\mathrm{C}$ of $\mathrm{O}$ & 282 & 15.1 & 39.2 & 1141 & 35.1 & 60.4 \\
\hline Total & 720 & 38.6 & 100 & 1889 & 58.1 & 100 \\
\hline Missing System & 1145 & 61.4 & & 1207 & 41.9 & \\
\hline Total & 1865 & 100 & & 3096 & 100 & \\
\hline
\end{tabular}

Source: Author's Data Analysis (2011)

A major responsibility of land administration machineries to the people is processing of title document to land whether such is formal and or informal. $23.5 \%$ of the respondents sampled in FCC possessed $\mathrm{C}$ of $\mathrm{O}, 15.1 \%$ did not while $61.4 \%$ were indifferent. In Minna, $23.0 \%$ of the sampled respondents possessed $\mathrm{C}$ of $\mathrm{O}, 35.1 \%$ were not having while $41.9 \%$ were indifferent. The perception of Land Owners wastherefore sought on the activities of land administration machineries in FCC and Minna as regards hindrances to processing of title document.Variables such as exorbitant processing cost, delay of process, extortion from government officials and lack of how to go about processing titlewere derived from respondents' perceptions and likert ranking of the variables was done to arrive at their mean values

Table 3.5 shows the 5- point linkert scale ranking of respondents' perception on reasons why respondents will not be willing to process title documents on land already allocated through land administration machineries and or lands bought via informal means. The Table also shows the Sum, Mean and Consensus Opinion of the respondents. Responses of respondents were sought using the above four (4) questions.

Table 3.5: Problems to Processing of Title Document

\begin{tabular}{|c|c|c|c|c|c|c|c|c|c|}
\hline $\begin{array}{l}\text { Study } \\
\text { Area }\end{array}$ & Problem & $\begin{array}{l}\text { Strongly } \\
\text { Agree } X^{5}\end{array}$ & Agree $X^{4}$ & $\begin{array}{l}\text { Disagree } \\
X^{3}\end{array}$ & $\begin{array}{l}\text { Strongly } \\
\text { Disagree } \\
\mathrm{X}^{2}\end{array}$ & $\begin{array}{l}\text { Indifference } \\
X^{1}\end{array}$ & Sum & Mean & Consensus Opinion \\
\hline \multirow[t]{4}{*}{ FCC } & $\begin{array}{l}\text { Exorbitant } \\
\text { Processing Cost }\end{array}$ & $270(1350)$ & $272(1088)$ & $201(603)$ & 559(1118) & $563(563)$ & 4722 & 2.53 & Not Sufficient Reason \\
\hline & Delay of Process & $577(2885)$ & $575(2300)$ & $426(1278)$ & $142(284)$ & $145(145)$ & 6892 & 3.70 & Good Reason \\
\hline & $\begin{array}{l}\text { Extortion from } \\
\text { Government } \\
\text { Officials }\end{array}$ & $560(2800)$ & $653(2612)$ & $220(660)$ & $169(338)$ & $263(263)$ & 6673 & 3.58 & Good Reason \\
\hline & $\begin{array}{l}\text { Lack of how to } \\
\text { go about title } \\
\text { processing }\end{array}$ & $251(1255)$ & $239(956)$ & $280(840)$ & $542(1084)$ & $553(553)$ & 4688 & 2.51 & Not Sufficient Reason \\
\hline \multirow[t]{4}{*}{ Minna } & $\begin{array}{l}\text { Exorbitant } \\
\text { Processing Cost }\end{array}$ & $1053(5265)$ & $898(3592)$ & $510(1530)$ & $344(1376)$ & 291(291) & 12,054 & 3.89 & Good Reason \\
\hline & Delay of Process & $826(4130)$ & $830(3320)$ & $950(2850)$ & $234(468)$ & $256(256)$ & 11,024 & 3.56 & Good Reason \\
\hline & $\begin{array}{l}\text { Extortion from } \\
\text { Government } \\
\text { Officials }\end{array}$ & $1052(5260)$ & $805(3220)$ & $800(2400)$ & $179(358)$ & $260(260)$ & 11,498 & 3.71 & Good Reason \\
\hline & $\begin{array}{l}\text { Lack of how to } \\
\text { go about title } \\
\text { processing }\end{array}$ & $172(860)$ & $186(744)$ & 201(603) & $816(1632)$ & $1721(1721)$ & 5,560 & 1.80 & Not Sufficient Reason \\
\hline
\end{tabular}

Source: Author's Data Analysis (2011) 
The analysis reveals that in FCC, Delay of process as well as extortion of money by government officials are sufficient reasons why individual land owners will not be willing to process title documents to land. While in Minna, Exorbitant Processing Cost, Delay of Process and extortion of money by government officials are factors militating against the desire of respondents to processing $\mathrm{C}$ of $\mathrm{O}$.

\subsection{Factors Militating Against the Performance of Land Administration Machineries in FCC, Abuja And Minna}

Interview with staff of AGIS reveals that hostility, fictitious claims, illiteracy as well as insistence on integration by customary owners of land in government layout concept are the challenges encountered by the land administration department.Encroachment on the land of another by adjourning land owner, cases of double allocation and multiple transactions are types of regular cases normally encountered by the department.Misapplication of premium collected is a major problem militating against effective land administration in FCC. In Minna on the other hand, interview reveals that Hostility, fictitious claims and illiteracy are the challenges encountered by the Ministry of Lands and Housing in the process of land acquisition from customary land owners. It also reveals that Allottees go contrary to the terms of the grant.

\section{Conclusion/Recommendations}

The results of this study have confirmed the level of involvement of land administration machineries in FCC and Minna in making land available to citizens. The activities of land administration machineries in FCC have proven to be highly favourable to citizens than what is obtainable in Minna.The study has also revealed that in FCC, Delay of process as well as extortion of money by government officials are sufficient reasons why individual land owners will not be willing to process title documents to land. While in Minna, Exorbitant Processing Cost, Delay of Process and extortion of money by government officials are factors militating against the desire of respondents to processing $\mathrm{C}$ of $\mathrm{O}$.

The land administration machineries most especially in Minna should always continue to advice the government on the benefits to accrue from making land available to the people, discourage all illegal acts on land transactions as well as enlighten and educate customary land owners on the need for compulsory acquisition.There should be Sustainable compensation to community whose lands are compulsorily acquired. In essence, compensation for unexhausted improvement should be based on the open market values.

The feedback from land owners would indicate that emphasis should be placed on provision of adequate income packages by government to officials of land administration at the study areas to discourage unhealthy acts in land transactions.

Government should ensure that constraints to land access due to land bureaucracy be removed. Also, government should be awaken to her responsibility by exhibiting the will and thoughts in ensuring that site and services schemes are the direction of the executive arm of government at all times. This will ensure a planned and orderly development of the districts and neighbourhoods in the face of the growing rate of the population in Abuja and Minna.

\section{References}

[1]. Ayedun, C.A and Oluwatobi, A.O (2011), Issues and Challenges Militating against the Sustainability of Affordable Housing Provision in Nigeria. Business Management Dynamics Vol.1, No.4, Oct 2011, pp. 01-08

[2]. Babade, T (2003). Access to Urban Land in Nigeria: An Analysis of the Activities of Lagos State Land Use and Allocation Committee.Paper in a book of Proceedings of a National Workshop Organized by the Department of Estate Management University of Lagos, Akoka Lagos Nigeria on the theme "Land Management and property Tax Reform in Nigeria. Pp $106-107,125,129$.

[3]. Food and Agriculture Organization of the United Nations (2010). What is Access to Land? Corporate Document Repository produced by Economic and Social Development Department. PDF Version

[4]. Gamu, F.A (2003). Land Management as a Veritable Tool for sustainable Development. A Paper in Book of Proceedings of a National Workshop Organized by the Department of Estate Management University of Lagos, Akoka, Lagos, Nigeria on the theme "Land Management and property Tax Reform in Nigeria. Pp 135

[5]. International Fund for Agricultural Development (2010), Land, Rural Poverty Portal. MHTMLDocument posted by Portal WebEditor.

[6]. Israel, G.D (2009). Determining Sample Size, PEOD6 Doc., One of the Series of the Agricultural Education and Communication Department, Florida Cooperative Extension Service, Instituteof Food and Agricultural Sciences, University of Florida. EDIS Website athttp://edis.ifas.ufl.edu.

[7]. Iseh, F.I (2003). Legal issues in land management in Nigeria. In M.M Omirin, T.O Nubi and A.Fawehinmi, eds., Land management and property tax reform in Nigeria. Lagos: Proceedings of a National Workshop orgainized by Department of Estate Management,University of Lagos, Akoka, Lagos, Nigeria.

[8]. Mabogunje, A.L (2003). Land Management in Nigeria: Issues, Opportunities and Threats. A Paper in Book of Proceedings of a National Workshop Organized by the Department of Estate Management University of Lagos, Akoka, Lagos, Nigeria on the theme "Land Management and property Tax Reform in Nigeria. Pp 25

[9]. National Bureau of Statistics/World Bank (2006). Core Welfare Indicators. Final DraftCopy, August 2006.

[10]. Nuhu, M.B (2011). An Assessment of Land Policy and Land Administration in the FederalCapital Territory, Nigeria. Thesis submitted to the School of Postgraduate, FederalUniversity of Technology, Minna

[11]. Ogedengbe, P.S (2004). Formulating a Good Urban Land Policy for Nigeria. J.Hum. Ecol., Vol15 no 2, pp92 
[12]. Omirin, M.M (2003). Issues in Land Accessibility in Nigeria.. A Paper in Book of Proceedings ofa National Workshop Organized by the Department of Estate Management University of Lagos, Akoka, Lagos, Nigeria on the theme "Land Management and property Tax Reformin Nigeria”. Pp 49-58

[13]. Sanusi, Y.A (2006). An Assessment of the Spatial Relationship between Poverty andEnvironmental Quality in Minna Metropolis, Niger State, Nigeria. A dissertationsubmittedto the Post Graduate School, Federal University of Technology, Minna.

[14]. Stanley, A.M and Orobowale, O (2011), Factors Influencing Land Accessibility for Housing Development in Abuja, Nigeria. Paper in Proceedings of the 2011 West Africa BuiltEnvironment Research (WABER) Conference held in Accra, Ghana between 19-21 July.

[15]. United Nations Economic Commission for Europe (2005). Land Administration in the UNECERegion; Development Trends and Main Principles, New York and Geneva.

[16]. United State Agency for International Development (2010). Land Tenure, Natural Resources Management and Development Portal. MHTML Document posted by Portal Web Editor. 